\title{
Comparative Study of Integrated Pest Management and Farmers Practices on Sustainable Environment in the Rice Ecosystem
}

\author{
Mohammad Zahangeer Alam, ${ }^{1}$ Md. Manjurul Haque, ${ }^{1}$ Md. Sirajul Islam, ${ }^{2}$ Emran Hossain, ${ }^{3}$ \\ Sabiha Binta Hasan, ${ }^{4}$ Shahela Binte Hasan, ${ }^{5}$ and Md. Sakhawat Hossain ${ }^{6}$ \\ ${ }^{1}$ Department of Environmental Science, Bangabandhu Sheikh Mujibur Rahman Agricultural University, Gazipur 1706, Bangladesh \\ ${ }^{2}$ Farm Management Division, Bangladesh Rice Research Institute (BRRI), Gazipur 1701, Bangladesh \\ ${ }^{3}$ Administration and Common Service, Bangladesh Rice Research Institute (BRRI), Gazipur 1701, Bangladesh \\ ${ }^{4}$ Jatiya Kabi Kazi Nazrul Islam University, Trishal, Mymensingh, Bangladesh \\ ${ }^{5}$ National University, Gazipur, Bangladesh \\ ${ }^{6}$ Ministry of Public Administration, Government of Bangladesh, Bangladesh
}

Correspondence should be addressed to Mohammad Zahangeer Alam; mohammad.alam@wsu.edu

Received 28 October 2015; Accepted 14 March 2016

Academic Editor: Thomas Iliffe

Copyright (C) 2016 Mohammad Zahangeer Alam et al. This is an open access article distributed under the Creative Commons Attribution License, which permits unrestricted use, distribution, and reproduction in any medium, provided the original work is properly cited.

\begin{abstract}
Integrated pest management (IPM) is an environmentally friendly technology. IPM is a multifaceted approach to pest management that seeks to minimize negative impacts on the environment. This technique is an important step towards providing healthy, viable food for a growing global population. The focus of this study was to examine the impact of integrated pest management in a rice agroecosystem. Currently, more than $80 \%$ of farmers rely on pesticides. IPM methods employed in our study had an impact on the number of healthy tillers and hills and grain weight. The lowest percentage of dead heart (1.03) and white head (2.00) was found in the IPM treated plots. These plots had an average yield of 7.4 tonne/ha. We found that there were significant differences between the treatment and the observed percentage of dead heart, grain weight, and yield. We conclude that IPM practices are an effective strategy for obtaining high rice yields while protecting the environment and creating a more sustainable agroecosystem. Furthermore, the need for ongoing research and training on IPM methods will be essential for creating a sustainable rice agroecosystem.
\end{abstract}

\section{Introduction}

Rice is a staple food for more than fifty percent of the world's population [1]. For decades rice crops have directly or indirectly played a key role in the livelihood of several billion people. In 2010, 154 million hectares of rice were cultivated worldwide, of which 137 million hectares were in Asia, with 48 million hectares harvested in Southeast Asia [2]. In Bangladesh, eighty percent of agricultural land is dedicated to rice cultivation [3]. Of the rice growing regions in Bangladesh, Barisal is one of the most important, due in part to the diversity of rice under cultivation. For this reason, as well as the region's consistently high yields, Barisal is known as the "Crop House of Bangladesh," although for several decades farmers have been plagued by a number of pest related issues [3].

Integrated pest management (IPM) is an adaptation to insect behavior and life cycles [4-6]. A farmer's agricultural practices and knowledge of pest species in a given agroecosystem are essential for developing a successful IPM plan [7]. An ecosystem level understanding of pest life cycles provides the basis for successful design and implementation of an IPM strategy. A farmer's practices and a well-designed IPM plan should be closely linked in rice ecosystems [8]. A successful IPM plan accounts for the protection of beneficial insects, secondary pest outbreaks, spread of disease, contamination of air, water, and soil resources, and pest resurgence $[9,10]$. The wide scale adoption of IPM in rice agroecosystem could 
provide a tremendous net benefit to farmers in a number of countries. The innovative IPM program utilized in this study is from the "Farmer Field School Model" [8] and is applicable to rice agroecosystems throughout the world. It protects against pesticide-induced pest resurgence, which is the primary focus of the National IPM program of any country in the world [8].

Two hundred sixty-six insect species have been identified in rice ecosystems in Bangladesh. These insects form a complex food web within the rice ecosystem. In the rice agroecosystem 42 insect species are considered to be pests $[11,12]$. Pest insect species can be categorized as minor and major pests. These pests cause severe damage to rice crops at different growth stages. The degree of damage is dependent on the growing season and surrounding environment [13].

One species, the yellow stem borer, Scirpophaga incertulas Walker, is considered to be a major rice pest [14]. According to DAE in Bangladesh [12] the stem borer can be eradicated through several methods: light trapping, hand picking eggs from rice leaves, sweeping with a net, perching, burning rice stubble, cultivation of insect resistant varieties, using bioagents, and applying Economic Threshold Level (ETL) based insecticides in Bangladesh. Currently, most rice farmers rely on insecticides rather than utilizing IPM strategies [15].

Integrated pest management (IPM) is an effective and environmentally friendly approach to pest management [16]. Sustainable and effective agricultural pest management techniques are important to the continued development of alternative pest management strategies [17]. IPM techniques protect the natural enemies of pest insects and aid in the restoration of ecosystem activities [18]. This approach takes advantages of all appropriate pest management options, including the judicious use of pesticides. Organic food production employs similar methods to IPM but precludes the use of pesticides that are produced from synthetic chemicals [19]. Notwithstanding this, at a community level worldwide, chemical pesticides have played a vital role in providing an abundant and inexpensive food source [20]. Despite this, the persistent use and overuse of chemicals in non-IPM treated farming systems have resulted in a number of adverse environmental problems [21]. For local farmers, continuing education and training play a vital role in advancing their knowledge of IPM practices and the adverse impacts agrochemicals can have on the rice ecosystem. Certain IPM practices have been shown to significantly increase yields while also increasing environmental and economic benefits. In the long run, IPM can be a better pest management strategy than chemical control alone [19]. IPM and farmers practices both are important for the protection of sustainable environment with rice yield. We conclude that the effect of IPM on the yield components would be further researched substantively in this region.

\section{Materials and Methods}

2.1. Geographical Position. The field experiment was conducted in the Barisal region of Bangladesh in 2010. Barisal is located in southern Bangladesh and encompasses an area of approximately 3,000 square kilometers. Barisal is bounded by Madaripur, Shariatpur, Chandpur, and Lakshmipur districts to the north; Patuakhali, Barguna, and Jhalokati districts to the south; Bhola and Lakshmipur districts to the east; Jhalokati, Pirojpur, and Gopalganj districts to the west. Our field site was located at $22.7000^{\circ} \mathrm{N} 90.3667^{\circ} \mathrm{E}$ and covers a total area of $324.41 \mathrm{~km}^{2}$ [22].

2.2. Farmer's Land Selection. To determine an appropriate field site a preliminary meeting was organized with farmers and personnel of the DAE in 2010 at their office in Barisal Sadar of Bangladesh. At this meeting, an observation was made of farmer's ongoing practices within their rice ecosystems. The experiment site was selected based on uniformity of cropland, the presence of major rice insects, cultivated rice varieties, and transplanting season. Yellow stem borer was considered as the major rice pest for this study. To maintain a degree of food security the Bangladesh Rice Research Institute (BRRI) releases numerous rice cultivars. Among these, BRRI dhan 28 and BRRI dhan 29 are popular among local farmers in the Barisal region due in part to yield performance during the Boro season (November to February). BRRI dhan 29 seed was supplied to the farmers for seedling preparation. Agronomic practices were applied according to guidelines established by the Bangladesh Rice Research Institute (BRRI) (Table 2). These practices include land preparation, fertilizer application, irrigation, and hand weeding. All documented practices in each plot were similar to the farmer's preexisting practices (Table 2). Insects' egg mass collection, perching, sweeping, and ETL based insecticides application are the most recognized components of an IPM strategy in rice agroecosystems (Table 1).

2.3. Data Collection. At each location we recorded the total number of hills per $10 \mathrm{~m}^{2}$, the average number of healthy tillers at tillering and flowering, the percentage of dead heart and white head, the percentage of moisture, and grain weight in $\mathrm{kg}$ per $10 \mathrm{~m}^{2}$ and yield (tonne/ha) (Figures 18). All agronomic and integrated farmer's pest management techniques were recorded for each plot (Tables 2 and 3). Major environmental concerns were determined through discussion with farmers and DAE personnel (Table 3).

2.4. Experimental Design and Statistical Analysis. The experiments were conducted during 2010-11 growing season in three locations within the Barisal region: Sarder Para, Uttar Sagardi, and Gabtala. Three fields owned by different farmers were selected from each location. The treatment plots were $12 \mathrm{~m} \times 12 \mathrm{~m}$ and separated from other plots by $1.6 \mathrm{~m}$ barrier zones designed to avoid spray drift or other treatment effects. Rice seedlings raised in the nursery were transplanted to the experimental plots with $20 \times 20 \mathrm{~cm}$ spacing, and recommended agronomic practices were followed. Each location was considered a replication. These three replicates, each of 4 treatments, produced a total of 12 plots for this study. Treatments were as follows: $T_{1}$ consisted of collection of egg masses, sweeping, and perching; $\mathrm{T}_{2}$ consisted of collection 
TABLE 1: Details of treatments in the rice agroecosystem in 2010-11.

\begin{tabular}{ll}
\hline Treatments & Description of each treatment \\
\hline $\mathrm{T}_{1}$ & $\begin{array}{l}\text { Collection of egg masses, sweeping, and perching: egg mass collection and sweeping both were employed at 7- } \\
\text { and 15-day intervals, respectively; sweeping was over before flowering of rice plants; bamboo perching was put } \\
\text { in the rice field } 10 \times 10 \mathrm{~m} \text { distance as nest for keeping birds in the rice fields as biological agent }\end{array}$ \\
\hline & $\begin{array}{l}\text { Collection of egg masses, sweeping, perching, and ETL based insecticides application: collection of egg masses, } \\
\text { sweeping, and perching activities were similar to treatment one; the rate of insecticides (Cartap) application was } \\
\mathrm{T}_{2}\end{array}$ \\
\hline $\begin{array}{l}\text { Prophylactic insecticides application: only insecticides were applied for three times of the total duration of rice } \\
\text { plant and dose was } 40 \mathrm{~mL} @ 10 \mathrm{~L} \text { water }\end{array}$ \\
\hline
\end{tabular}

TABLE 2: Agronomic practices in each plot in the rice ecosystem in 2010-11.

\begin{tabular}{|c|c|c|c|c|c|c|}
\hline Locations & $\begin{array}{l}\text { Treated } \\
\text { plots }\end{array}$ & $\begin{array}{l}\text { Number of tillage } \\
\text { processes during } \\
\text { land preparation }\end{array}$ & $\begin{array}{c}\text { Transplanting } \\
\text { time } \\
\text { (November) }\end{array}$ & Fertilizer application (g/decimal) & Weeding & Sources of waters \\
\hline \multirow{4}{*}{ Sarder Para } & $\mathrm{T}_{1}$ & 4 & Mid & Urea 250, TSP 300, MOP400 & By hand & Rain and flash flood water \\
\hline & $\mathrm{T}_{2}$ & 4 & Mid & Urea 250, TSP 300, MOP400 & By hand & Rain and flash flood water \\
\hline & $\mathrm{T}_{3}$ & 4 & Mid & Urea 250, TSP 300, MOP400 & By hand & Rain and flash flood water \\
\hline & $\mathrm{T}_{4}$ & 4 & Mid & Urea 250, TSP 500, MOP400 & By hand & Rain and flash flood water \\
\hline \multirow{4}{*}{ Uttar Sagardi } & $\mathrm{T}_{1}$ & 5 & Mid & Urea 250, TSP 300, MOP300 & By hand & Rain and flash flood water \\
\hline & $\mathrm{T}_{2}$ & 5 & Mid & Urea 300, TSP 500, MOP400 & By hand & Rain and flash flood water \\
\hline & $\mathrm{T}_{3}$ & 5 & Mid & Urea 250, TSP 500, MOP300 & By hand & Rain and flash flood water \\
\hline & $\mathrm{T}_{4}$ & 5 & Mid & Urea 250, TSP 500, MOP300 & By hand & Rain and flash flood water \\
\hline \multirow{4}{*}{ Gabtala } & $\mathrm{T}_{1}$ & 5 & Mid & Urea 250, TSP 300, MOP300 & By hand & Rain and flash flood water \\
\hline & $\mathrm{T}_{2}$ & 5 & Mid & Urea 300 , TSP 500, MOP400 & By hand & Rain and flash flood water \\
\hline & $\mathrm{T}_{3}$ & 5 & Mid & Urea 250, TSP 500, MOP300 & By hand & Rain and flash flood water \\
\hline & $\mathrm{T}_{4}$ & 5 & Mid & Urea 250, TSP 500, MOP300 & By hand & Rain and flash flood water \\
\hline
\end{tabular}

TABLE 3: Record of farmers' practices in the rice ecosystem in 2010-11.

\begin{tabular}{|c|c|c|c|c|}
\hline $\begin{array}{l}\text { Components of } \\
\text { integrated practices }\end{array}$ & Sarderpara & Uttarsagardi & Gabtala & $\begin{array}{l}\text { Major threats/Environmental } \\
\text { degradation }\end{array}$ \\
\hline $\begin{array}{l}\text { Collection of egg } \\
\text { mass }\end{array}$ & Not applied & Not applied & Not applied & \multirow{4}{*}{$\begin{array}{l}\text { Reduction of beneficial insects, } \\
\text { toxicity to soil, air, and water, } \\
\text { health hazards, and outbreak of } \\
\text { secondary pests } \\
\text { Higher cost to benefit ratio and } \\
\text { microbial toxicity }\end{array}$} \\
\hline Sweeping & Not applied & Not applied & Not applied & \\
\hline Perching & $\begin{array}{l}\text { Applied at tillering } \\
\text { stage }\end{array}$ & $\begin{array}{l}\text { Applied at tillering } \\
\text { stage }\end{array}$ & $\begin{array}{l}\text { Applied at tillering } \\
\text { stage }\end{array}$ & \\
\hline $\begin{array}{l}\text { Application of } \\
\text { insecticides }\end{array}$ & Cartap & Cartap & Cartap & \\
\hline
\end{tabular}

of egg masses, sweeping, perching, and ETL based insecticides application; $\mathrm{T}_{3}$ consisted of application of prophylactic insecticides; and $\mathrm{T}_{4}$ was the farmers' "normal" pest control strategy (Table 1). The experiment was laid out as a RCBD design. Data were analyzed using Statistix 10.

\section{Results}

3.1. Tiller and Hill. The number of healthy tillers was similar for all treated plots at each location (Figures 1 and 2). The total number of hills per $10 \mathrm{~m}^{2}$ varied from 194 to 270 (Figure 5). This was statistically nonsignificant (Table 4).

3.2. Dead Heart. At Sarder Para, the average percentage of dead heart was 2.25, 0.9, 1 , and 3 at $\mathrm{T}_{1}, \mathrm{~T}_{2}, \mathrm{~T}_{3}$, and $\mathrm{T}_{4}$, respectively. For Uttar Sagardi the percentage of dead heart was $2,1,1.18$, and 2.5 for $\mathrm{T}_{1}, \mathrm{~T}_{2}, \mathrm{~T}_{3}$, and $\mathrm{T}_{4}$. The lowest percentage of dead heart (1.03) was found in treatment $\mathrm{T}_{2}$, with the highest (2.83) being recorded for $\mathrm{T}_{4}$. For Gabtala 


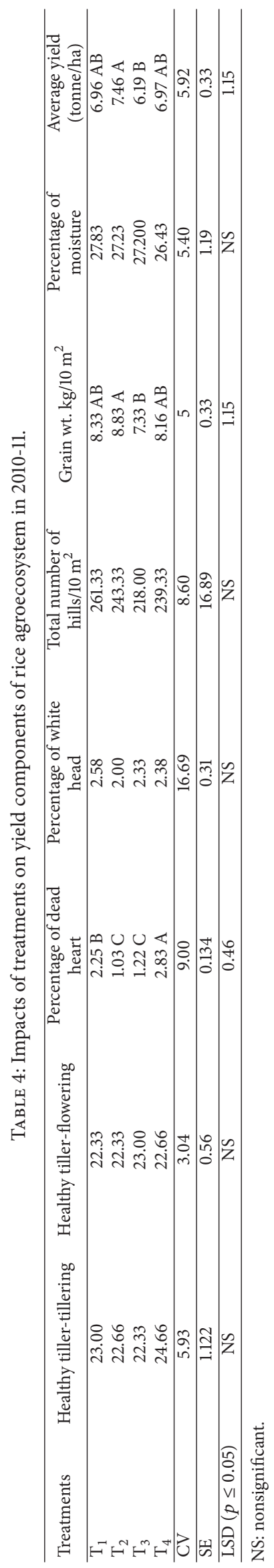




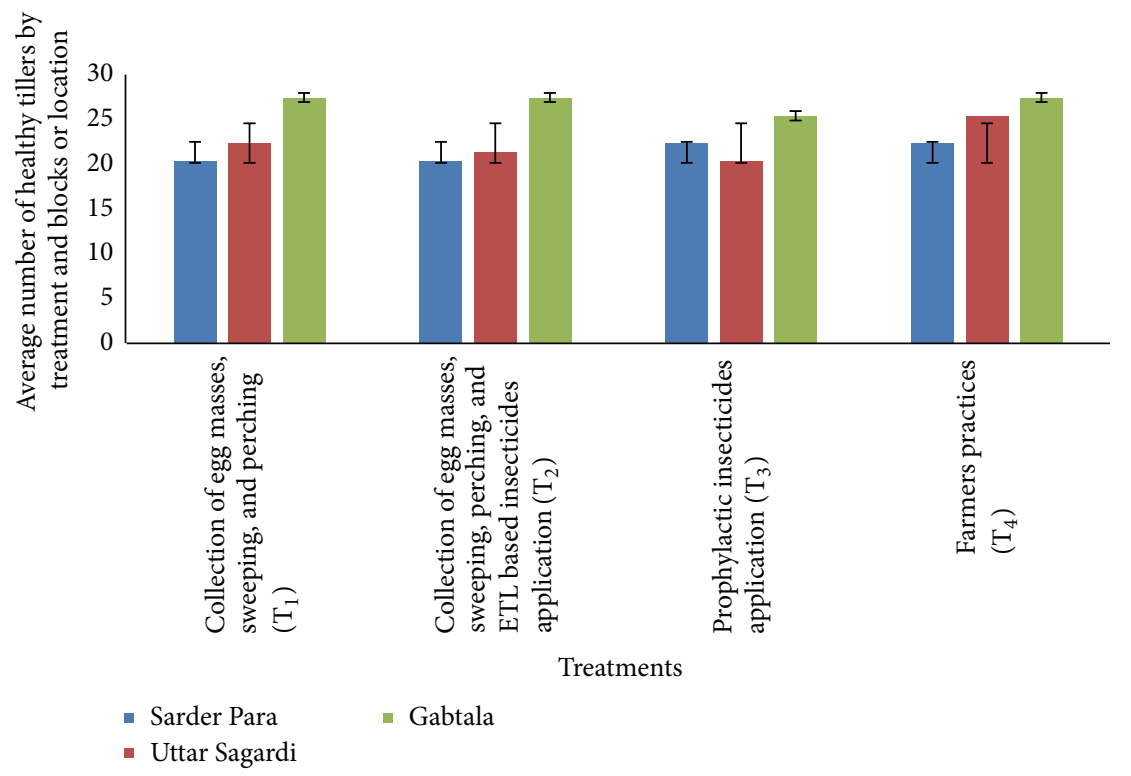

Figure 1: Outline of the different treatments.

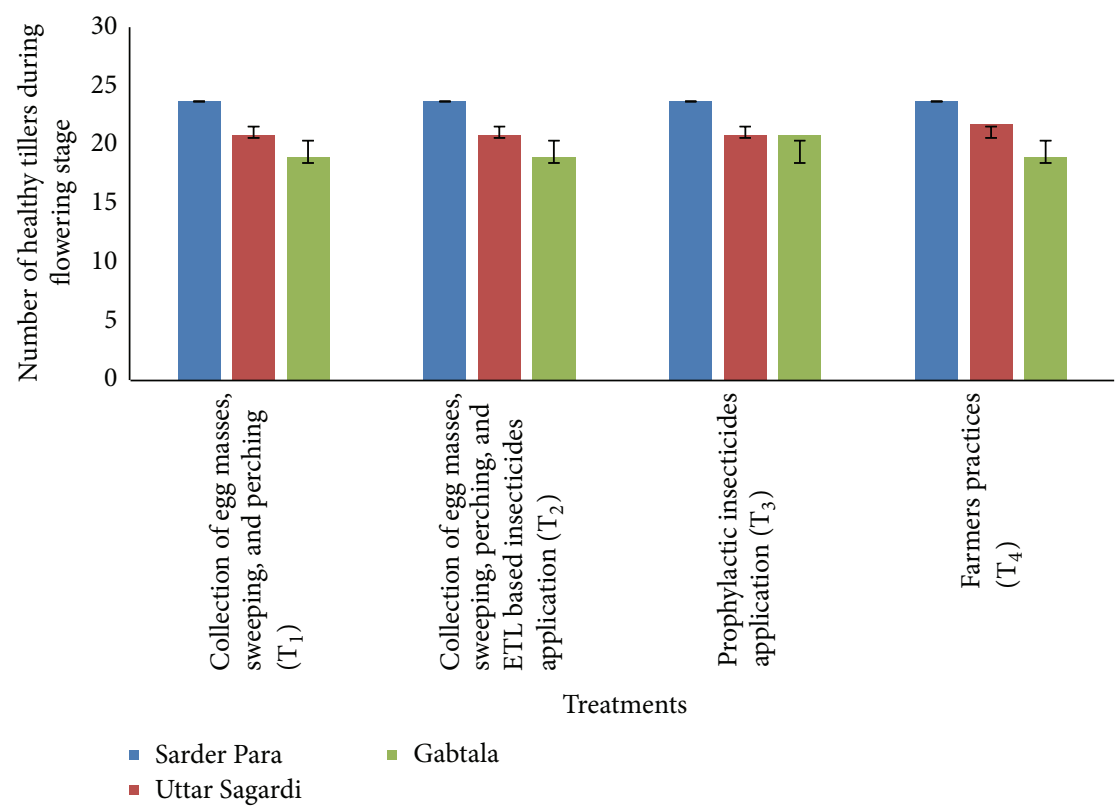

FIGURE 2: The number of healthy tillers by treatments.

the range of dead heart was from 1.2 to 3 percent. There was a significant difference between the percentage of dead heart and treatments $(p \leq 0.05)$. Treatments 2 and 3 were statistically identical, but $\mathrm{T}_{1}$ treated plots were statistically different from $\mathrm{T}_{4}$ treated plots (Figure 3 and Table 4).

3.3. White Head. At Sarder Para the percentage of white head was observed to be 2.86, 2.74, 2.5, and 2.15 for treatments $\mathrm{T}_{1}, \mathrm{~T}_{2}, \mathrm{~T}_{3}$, and $\mathrm{T}_{4}$, respectively. In Uttar Sagardi, the percentage of white head was 2, 1.52, 2, and 2 for treatments $T_{1}, T_{2}, T_{3}$, and $T_{4}$. Percentage of white head observed in Gabtala was 2.88, 1.75, 2.5, and 3 for treatments $\mathrm{T}_{1}-\mathrm{T}_{4}$. The lowest percentage of white head (2.00) was found in $\mathrm{T}_{2}$ treated plots. However this relation was statistically nonsignificant (Table 4 and Figure 4).

3.4. Grain Weight $\left(\mathrm{kg} / 10 \mathrm{~m}^{2}\right)$. A $7 \mathrm{~kg}$ grain weight was found at $\mathrm{T}_{1}, \mathrm{~T}_{3}$, and $\mathrm{T}_{4}$ treated plots, and $8 \mathrm{~kg}$ was found in $\mathrm{T}_{2}$ treated plot at Sarder Para. In Uttar Sagardi, the range of grain weight was 8.5 to $10.5 \mathrm{~kg} / 10 \mathrm{~m}^{2}$, but similar grain weight was found in $\mathrm{T}_{1}$ and $\mathrm{T}_{4}$ treated plots. The lowest was found in the treatment of $\mathrm{T}_{3}$ at Gabtala (Figure 6). A 


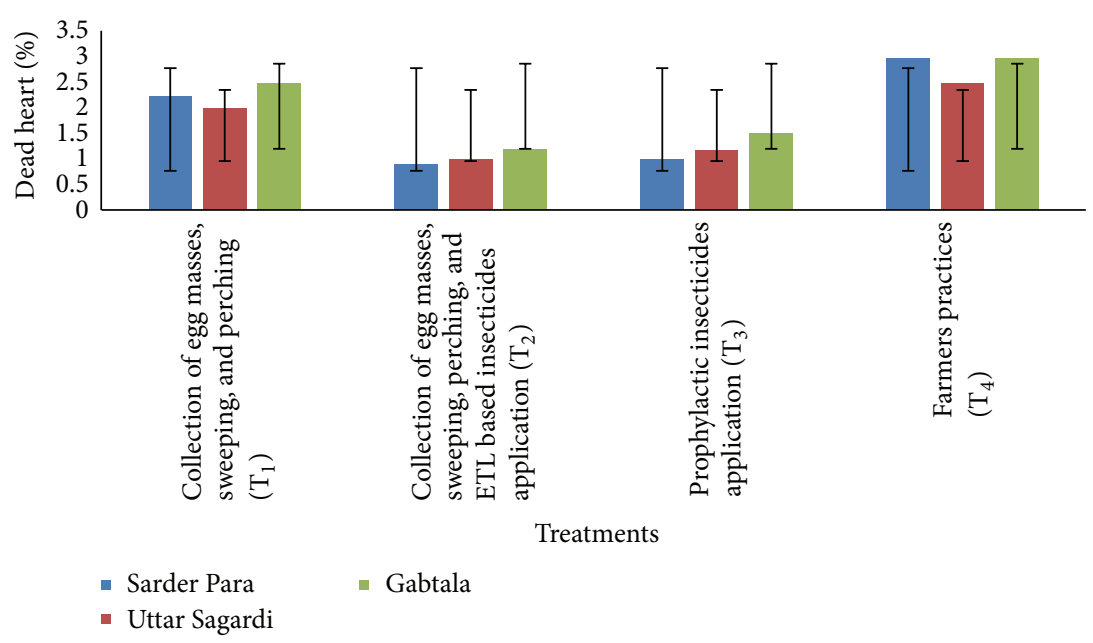

Figure 3: Percentage of dead heart by treatments.

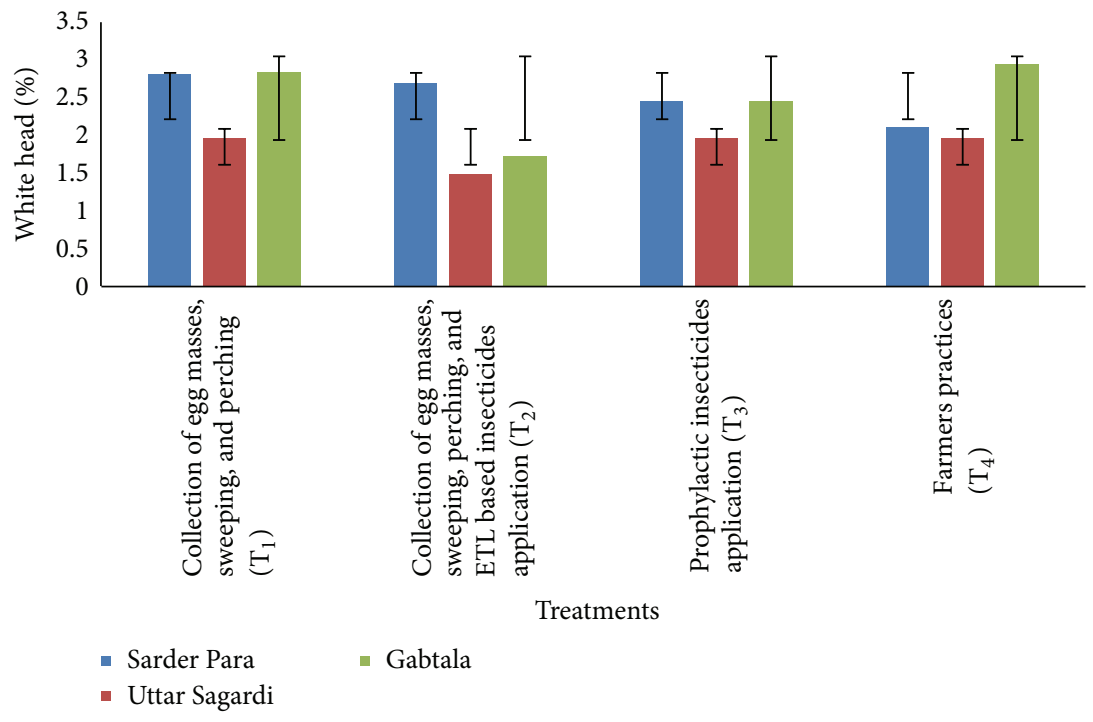

FIgURE 4: Percentage of white head by treatments.

significantly higher average grain weight (8.83) was found for $\mathrm{T}_{2}$ treated plots. The relationship between treatment and grain weight was significant $(p \leq 0.05)$. The percentage of white head in $\mathrm{T}_{1}$ treated plots was identical with $\mathrm{T}_{3}$ and $\mathrm{T}_{4}$ treated plots. $\mathrm{T}_{2}$ treated plots were statistically different from $\mathrm{T}_{3}$ (Table 4).

3.5. Moisture Content. Moisture content in rice grains at Sarder Para was 26, 26.7, 23.7, and 23.2\% in treated plots $\mathrm{T}_{1}, \mathrm{~T}_{2}, \mathrm{~T}_{3}$, and $\mathrm{T}_{4}$, respectively. Similarly, at Uttar Sagardi, 29.5, 28, 29.8, and 27.1\% moisture contents were found in $\mathrm{T}_{1}, \mathrm{~T}_{2}, \mathrm{~T}_{3}$, and $\mathrm{T}_{4}$. The range of moisture percentage was found to be 27 to $29 \%$ at Gabtala (Figure 7). Variation in the moisture content of rice grains was not statistically significant among treatments (Table 4).

3.6. Yield (Tonne/ha). Rice yields of $6.02,6.81,6.21$, and 6.25 tonne/ha were found at $\mathrm{T}_{1}, \mathrm{~T}_{2}, \mathrm{~T}_{3}$, and $\mathrm{T}_{4}$ treated plots in Sarder Para. In Uttar Sagardi, rice yields of 8.19, 8.79, 6.93, and 8.47 tonne/ha were recorded at $\mathrm{T}_{1}, \mathrm{~T}_{2}, \mathrm{~T}_{3}$, and $\mathrm{T}_{4}$ treated plots. A similar trend was observed at Gabtala plots with $6.69,6.79,5.44$, and 6.19 tonne/ha being recorded for $\mathrm{T}_{1}, \mathrm{~T}_{2}, \mathrm{~T}_{3}$, and $\mathrm{T}_{4}$ plots, respectively. An average yield of 7.4 tonne/ha was highest in $\mathrm{T}_{2}$ (IPM) treated plots. We found the relationship between treatment and yield to be significant $(p \leq 0.05)$. Rice yield in $\mathrm{T}_{1}$ treated plots was identical with $\mathrm{T}_{3}$ and $\mathrm{T}_{4}$ treated plots. Treatment $\mathrm{T}_{2}$ was statistically different from $\mathrm{T}_{3}$ treated plots (Table 4 and Figure 8).

3.7. Major Threats Raised for a Sustainable Environment. In the last 10 years, farmers have not fully implemented all of the components of integrated pest management practices. Currently, more than $90 \%$ of farmers rely on Cartap insecticides for control of rice insects in rice agroecosystems [23]. Egg mass collection, sweeping, perching, and ETL based 


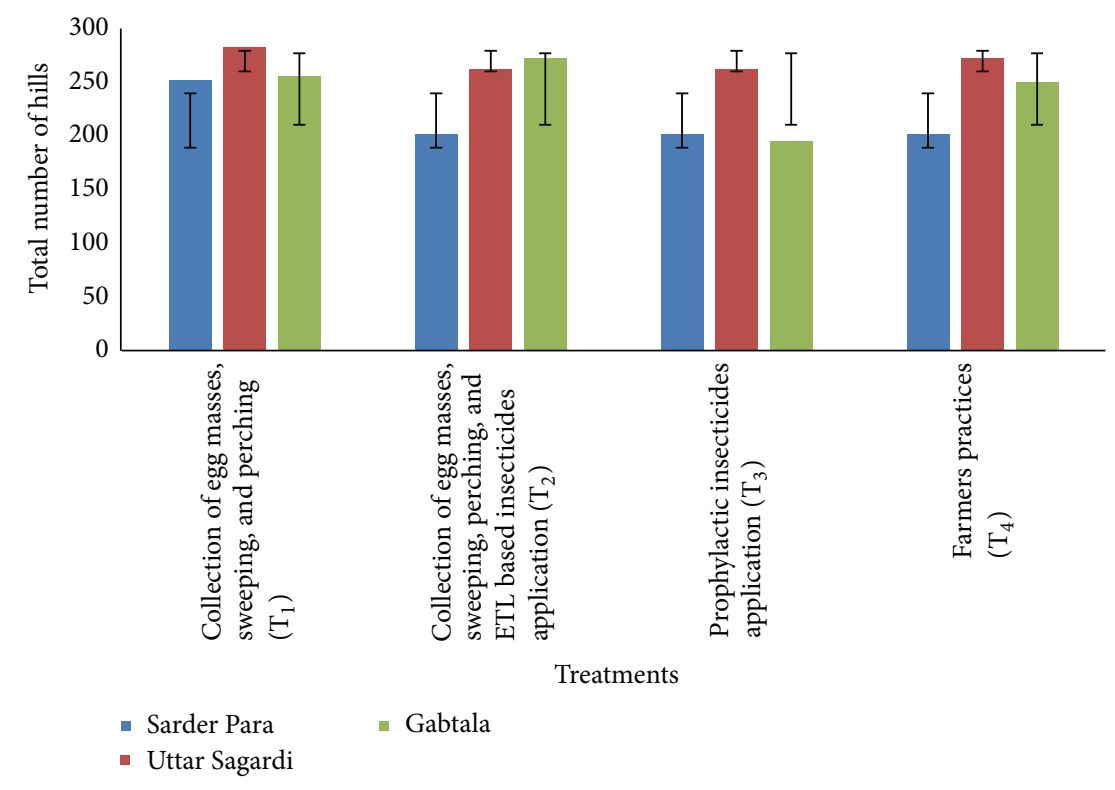

FIGURE 5: Total number of hills per $10 \mathrm{~m}^{2}$.

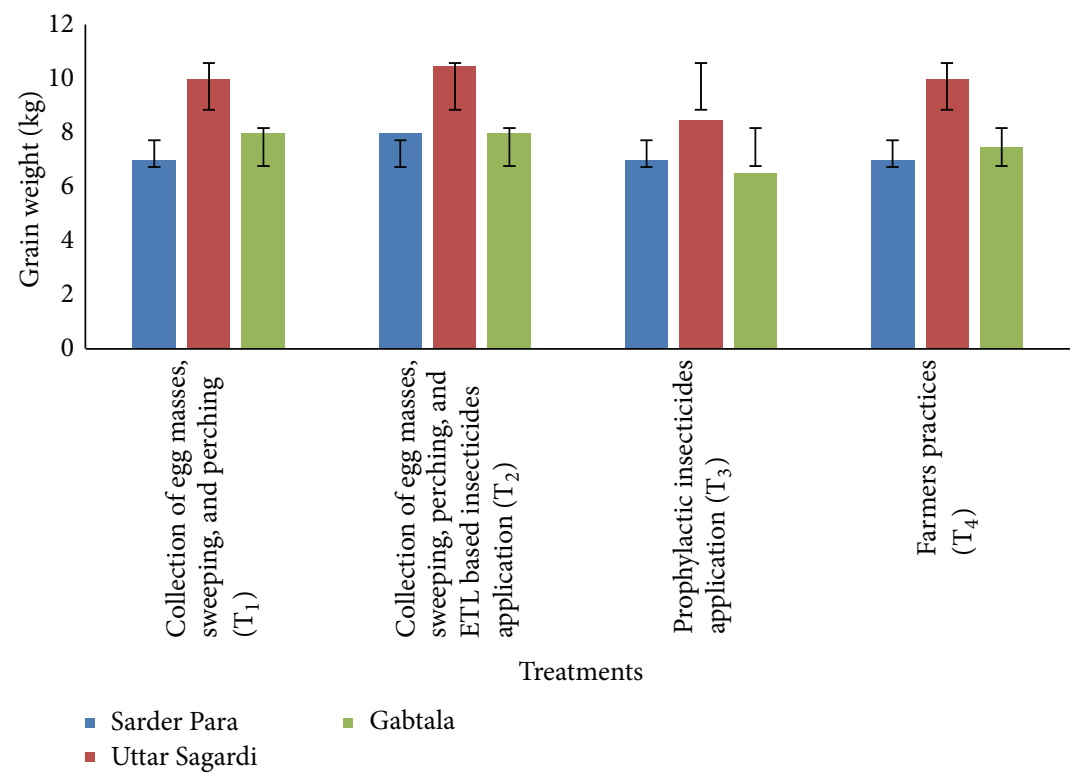

FIgURE 6: Average grain weight.

insecticides application are the recommended practices for the control of pest insects in the rice ecosystem. Due to the lack of integrated methods for control of major rice pest threats to the system problems include reduction of beneficial insects, outbreak of secondary pests, high cost to benefit ratio, impacts on beneficial microbes, the accumulation of toxins in soil and water bodies, and the associated health hazards [13]. Information pertaining to environmental degradation was garnered through discussions with farmers and Department of Agricultural Extension (DAE) personnel in Bangladesh (Table 3).

\section{Discussion}

Integrated pest management (IPM) is a highly effective method for managing pest insect species [24]. This management system enriches ecosystem processes and can provide a healthy, sustainable food source for a range of organisms [25]. Rice agroecosystems have evolved over the last 5,000 years under human management; for this reason human beings are considered to be an integral component. An abundance of insect species are supported through a series of complex interactions that comprise the food web that at its base is 


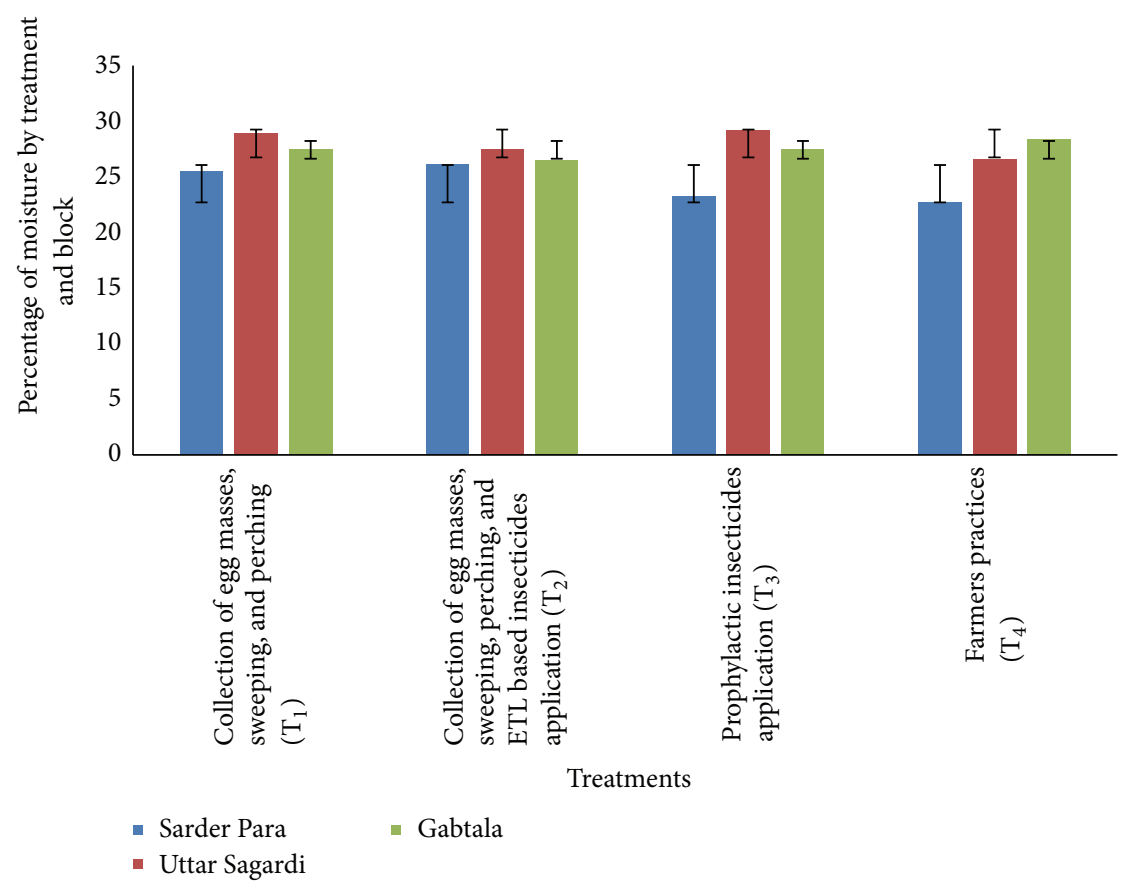

Figure 7: Moisture content.

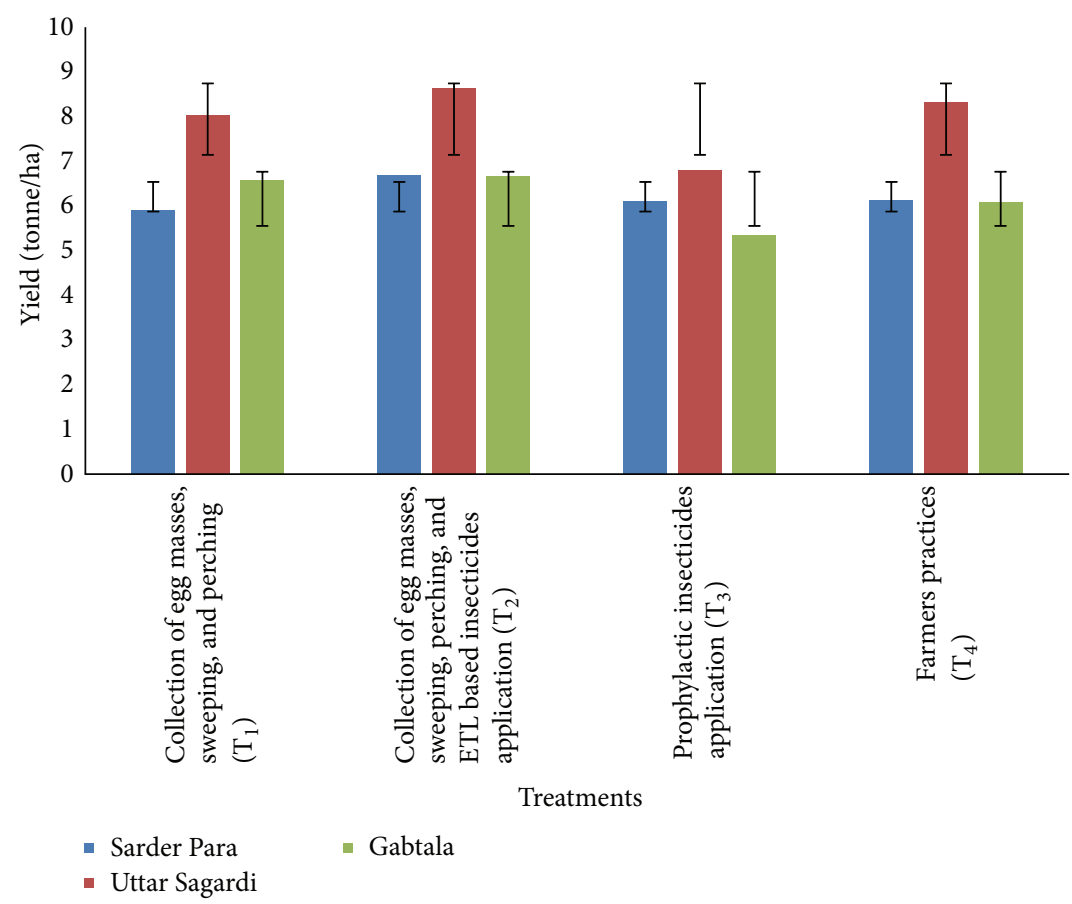

Figure 8: Yield.

maintained by rice [26]. In this agroecosystem, the food web can serve as a tool to help improve natural ecosystem functions. However, function is dependent upon the continued propagation of predator insect species. Ecosystem function in a healthy rice agroecosystem can be improved through protecting and encouraging those insects that prey on pest species [27]. In conventional pest management strategies the role of predator species is minimized or even eliminated by heavy pesticide application (Table 3). In China, 889 insect species that prey on pest insects have been identified. These predator insect species account for $64.74 \%$ of all naturally occurring enemies of pest species [28].

Increased pesticide use has led to an increase in soil, water, and air pollution. These increases have in turn had an 
adverse impact on human health and rice quality [29]. The incorrect use or overuse of pesticides can harm plants, aquatic organisms, livestock, and humans. Jacobsen and Hjelmsø [30] reported that pesticide use has a higher cost to benefit ratio with respect to yields and can have negative impacts on beneficial microbes. The excessive use of pesticides, in the search for higher yields, has triggered several ecological crises (Table 3). These crises include pesticide resistance, resurgence of insect pests, pesticide poisoning, environmental toxicity, destruction and elimination of natural predator species, effects on nontarget organisms, disruption in the food web, and increased prevalence of pesticide residues in food [31, 32]. These conditions could be effectively mitigated through implementation of a well-designed IPM strategy [32, 33]. Despite several IPM strategies that have been developed and promoted for rice production, adoption remains low due to the "chemical-free" strategies being less effective when compared to heavy insecticide application. Successful IPM strategies need to incorporate a combination of techniques and low to moderate insecticides application [34].

Integrated pest management and farmer practices both have a significant effect on the number of rice hills, abundance of healthy tillers, and the percentage of white head and dead heart (Table 3 ). In addition these practices can affect grain weight and yield. We found the incidence of dead heart and white heart both to be relatively lower in the IPM treated plots; the percentage of white head and dead heart both was observed to be lower than established critical limits [35]. Other parameters such as hills, tiller, and grain weight were variable, but yield (7.4 tonne/ha) was higher in the IPM treated plots (Table 3). Singh et al. [36] conducted similar research on the effectiveness of IPM for Rice Yellow Stem Borer (Scirpophaga incertulas) in rice-wheat cropping systems. They found similar incidence of dead heart and white head in their IPM treatments. Several other studies have shown that a well-designed IPM program can control pest insects in an ecologically friendly manner [37].

One hundred fifty-nine rice insect species are recorded in the rice agroecosystem. Among these species, 20-23 species have been found to be most damaging in Bangladesh [38]. Due to lack of knowledge pertaining to insect life cycles and pest species, farmers often apply pesticides at higher rates and at inappropriate times. A majority of farmers are not concerned with the negative impacts pesticide use may have on fish, wildlife, humans, soil, and beneficial insect species [39]. Additional education and training are needed to better inform farmers of responsible pest management techniques and appropriate pesticide application. This could be accomplished through television programming, increased contact with extension personnel, and farm credit services. An increased awareness of the correct application of agrochemicals, pest monitoring, and timely removal of weeds and diseased plants will protect the environment and decrease the financial burden on farmers [40]. By increasing the number of IPM-trained farmers, smaller quantities of pesticides will be put into the rice agroecosystem [32].

Most farmers do not understand the impacts pesticide use can have on their health. This is most often due to the lack of knowledge surrounding pesticide's mode of action. Research has been conducted on health disorders associated with the use of nonrecommended pesticides and inappropriate applications rates. One study examined negative health effects observed in rural Vietnamese communities. It was found that a majority of farmers suffer from fatigue, headache, and dizziness, most often occurring during and after pesticide application. These neurological symptoms were found to be the result of cholinesterase inhibition [41]. Insecticides are moderately hazardous due to the known health effects associated with exposure $[42,43]$. Health problems associated with overuse of pesticides have risen despite increased availability and use of protective measures $[43,44]$.

Farmers often become dependent on pesticides without giving consideration to the environmental consequences. Unfortunately this is a common occurrence because there is less concern for environmental protection when food production takes precedence, as is often the case in the developing world. Recently there is a growing concern among scientists about the fate of pesticides in these agricultural settings [6]. The use of IPM can reduce pesticides applications up to $85 \%$ [45]. Selective pesticide use can reduce pest populations and improve ecosystem services. A study was examined on pesticide use and attitudes toward pest management strategies among rice and rice-fish farmers in the Mekong Delta [43]. They identified patterns of pesticide use and possible integration of IPM strategies for control of major rice pests. They found that farmers who did not employ IPM methods frequently experienced negative health effects associated with pesticide use [43]. Integration of IPM practices may serve to improve farmer awareness of sustainable practices through emphasizing the importance of healthy rice ecosystems.

IPM techniques are able to increase agricultural productivity while reducing pesticide use in crop systems. Pretty et al. [46] found IPM technology to be effective at reducing pesticide use by around $71 \%$, while increasing yields by $42 \%$. In China, annual sweet potato production has increased by $30 \%$, due to implementation of IPM techniques. The economic benefits of IPM have been included in annual revenue reports in the United States [47, 48]. In Africa, the introduction of an exotic wasp, Anagyrus lopezi (DeSantis), for the control of cassava mealybug, Phenacoccus manihoti Matile-Ferrero, has resulted in an average annual return of 300 dollars (US) per farmer [47, 49]. Additional reported benefits for implementation of IPM strategies range from 100 to 500 dollars (US) per hectare of productive land [50]. In the West Indies IPM has been used in banana cultivation and has led to a $65 \%$ decrease in pesticide use over the last 10 years [51]. Research was conducted on IPM and non-IPM treated farms in India for productivity and sustainability; they found that sustainable production was higher in the IPM treated farms [32]. Numerous studies have concluded that IPM techniques are extremely efficient and environmentally friendly and are the foundation of sustainable cropping systems. It is worth noting that no single technology can solve all pest problems.

Most rice farmers currently have practices that are similar to designed IPM strategies. Despite this, due to a lack of proper training on IPM practices in the rice ecosystem, 
farmer activities have been damaging to both the environment and human health [52]. An increased reliance on pesticides has proven to be unsustainable and not cost efficient $[23,43,53]$. Pesticides compatible with IPM strategies have been shown to be beneficial for the control of rice pests during the germination, tillering, vegetative growth, and flowering [54]. IPM strategies that employ appropriate pesticide use have consistently been shown to increase rice production $[21,55]$.

We conclude that to increase adoption of IPM strategies it is necessary to increase farmer awareness and knowledge concerning environmental pollution that could be mitigated with successful implementation of these techniques. It is important to improve farmers' pest management practices through examining current strategies and building upon preexisting knowledge. Additional research is needed to identify insect resistant rice varieties, analyze the patterns and use of pesticides, investigate constraints to controlling rice pests, examine the level of knowledge that farmers have concerning environmental pollution due to pesticide application, and explore alternative ways to reduce pesticide use.

\section{Conclusion}

Integrated pest management practices are infrequently being utilized for pest control in rice agroecosystems. The principle benefits of this technique include improved environmental conditions and healthier cropping systems. Healthy agroecosystems can provide higher rice yields than current management strategies. In our study BRRI dhan 29 rice yielded 7.4 tonne/ha in the IPM treated plots. According to BRRI (2015) the cultivar BRRI dhan 29 is capable of yields from 6 to 8 tonne/ha in Bangladesh agroclimatic zones (http://www.brri.gov.bd/). Our study indicates that an IPM strategy can have a positive effect on yield performance while lessening the environmental impacts associated with chemical intensive pest control.

\section{Competing Interests}

The authors declare that there are no competing interests regarding the publication of this paper.

\section{Acknowledgments}

The authors would like to thank the Integrated Agriculture Productivity Project (IAPP) and the Ministry of Agriculture in Bangladesh for providing funding and research facilities.

\section{References}

[1] International Rice Research Institute (IRRI), Bringing Hope, Improving Lives: Strategic Plan 2007-2015, International Rice Research Institute (IRRI), Los Banos, Laguna, Philippines, 2006.

[2] Food and Agriculture Organization Stat (FAOSTAT), 2012, http://faostat.fao.org/.
[3] Department of Agriculture Extension (DAE), 2010, http://www dae.gov.bd/.

[4] S. Petit, K. Haysom, R. Pywell et al., "Habitat-based models for predicting the occurrence of ground-beetles in arable landscapes: two alternative approaches," Agriculture, Ecosystems and Environment, vol. 95, no. 1, pp. 19-28, 2003.

[5] B. D. Roitberg, "Why pest management needs behavioral ecology and vice versa," Entomological Research, vol. 37, no. 1, pp. 14-18, 2007.

[6] F. Vinatier, F. Lescourret, P.-F. Duyck, and P. Tixier, "From IBM to IPM: using individual-based models to design the spatial arrangement of traps and crops in integrated pest management strategies," Agriculture, Ecosystems \& Environment, vol. 146, no. 1, pp. 52-59, 2012.

[7] M. Rahman, "Problems and suggestions for farmers' adoption of IPM practices in rice (Oryza sativa L) Cultivation," Bangladesh Journal of Agricultural Research, vol. 37, no. 1, pp. 121-128, 2012.

[8] C. Thorburn, "The rise and demise of integrated pest management in rice in Indonesia," Insects, vol. 6, no. 2, pp. 381-408, 2015.

[9] J. Mangan and M. S. Mangan, "A comparison of two IPM training strategies in China: the importance of concepts of the rice ecosystem for sustainable insect pest management," Agriculture and Human Values, vol. 15, no. 3, pp. 209-221, 1998.

[10] National Pesticides Information Center in USA, 2015, http:// npic.orst.edu/envir/beneficial/index.html.

[11] S. K. Srivastava, D. K. R. Biswas, B. K. G. Garg, N. M. M. M. Haque, P. Ijaj, and S. N. Tiwari, Management of Stem Borers of Rice and Wheat in Rice-wheat System of Pakistan, Nepal, India and Bangladesh, vol. 17 of Rice-Wheat Consortium Paper, RiceWheat Consortium for the Indo-Gangetic Plains, New Delhi, India, 2004.

[12] Department of Agriculture Extension (DAE), 2011, http://www .dae.gov.bd/site/search?key=Department+of+Agriculture+Extension+\%28DAE\%29\%2C+2011.

[13] A. Khaliq, M. Javed, M. Sohail, and M. Sagheer, "Environmental effects on insects and their population dynamics," Journal of Entomology and Zoology Studies, vol. 2, no. 2, pp. 1-7, 2014.

[14] S. Chatterjee and P. Mondal, "Management of rice yellow stem borer, Scirpophaga incertulas Walker using some bio rational insecticides," Journal of Bio Pesticides, vol. 7, pp. 143-147, 2014.

[15] M. Mohiuddin, M. M. Hossain, A. K. M. M. Rahman, and M. S. Palash, "Socio-economic study of insecticide use on vegetable cultivation at farm level in Chittagong region," Journal of the Bangladesh Agricultural University, vol. 7, no. 2, pp. 343-350, 2009.

[16] M. H. Kabir and R. Rainis, "Do farmers not widely adopt environmentally friendly technologies? Lesson from Integrated Pest Management (IPM)," Modern Applied Science, vol. 9, no. 3, pp. 208-215, 2015.

[17] J. Pretty and Z. P. Bharucha, "Integrated Pest Management for sustainable intensification of agriculture in Asia and Africa," Insects, vol. 6, no. 1, pp. 152-182, 2015.

[18] S. E. Naranjo, P. C. Ellsworth, and G. B. Frisvold, "Economic value of biological control in integrated pest management of managed plant systems," Annual Review of Entomology, vol. 60, pp. 621-645, 2015.

[19] United States Environmental Protection Agency (EPA), 2014, http://www.epa.gov/agriculture/tipm.html. 
[20] US Environmental Protection Agency, "Agricultural Pesticides: management improvements needed to further promote Integrated Pest Management," 2015.

[21] S. Arora, I. Mukherji, A. Kumar, and R. K. Tanwar, "Pesticide residue analysis of soil, water, and grain of IPM basmati rice," Environmental Monitoring and Assessment, vol. 186, no. 12, pp. 8765-8772, 2014.

[22] Bangladesh Bureau of Statistics Region Census (BBS), 2011, http://www.bbs.gov.bd/WebTestApplication/userfiles/Image/ LatestReports/YB2011.pdf.

[23] M. Z. Alam, "Survey and assessment of insect management technologies and environmental impact on rice ecosystem of Bangladesh," International Journal of Applied Research and Studies, vol. 2, no. 4, pp. 1-16, 2013.

[24] D. Abrol, Integrated Pest Management: Current Concepts and Ecological Perspective, 2013.

[25] R. J. Hillocks and J. E. Cooper, "Integrated Pest Managementcan it contribute to sustainable food production in Europe with decreased reliance on conventional pesticides?" 2012, http:// www.eucipm.org/docs/IPM-Can-it-Deliver-DiscussionPaperNolb.pdf.

[26] S. K. Redfern, N. Azzu, and J. S. Binamira, "Rice in Southeast Asia: facing risks and vulnerabilities to respond to climate change," 2015, http://www.fao.org/docrep/017/i3084e/ i3084e18.pdf.

[27] M. Allara, S. Kugbei, F. Dusunceli, and G. Gbehounou, "Coping with changes in cropping systems: plant pests and seeds," in Proceedings of the Joint FAO/OECD Workshop on Building Resilience for Adaptation to Climate Change in the Agriculture Sector, pp. 91-102, Rome, Italy, April 2012.

[28] Y. G. Lou, G. R. Zhang, W. Q. Zhang, Y. Hu, and J. Zhang, "Biological control of rice insect pests in China," Biological Control, vol. 67, pp. 8-20, 2013.

[29] M. A. Sattar, M. Z. Alam, and M. M. Rahaman, "The farm use of pesticides and the guidelines of pesticides research in Bangladesh," Bangladesh Journal of Environmental Science, vol. 10, pp. 313-317, 2004.

[30] C. S. Jacobsen and M. H. Hjelmsø, "Agricultural soils, pesticides and microbial diversity," Current Opinion in Biotechnology, vol. 27, pp. 15-20, 2014.

[31] M. W. Aktar, D. Sengupta, and A. Chowdhury, "Impact of pesticides use in agriculture: their benefits and hazards," Interdisciplinary Toxicology, vol. 2, no. 1, pp. 1-12, 2009.

[32] R. Sharma, R. Peshin, U. Shankar, V. Kaul, and S. Sharma, "Impact evaluation indicators of an Integrated Pest Management program in vegetable crops in the subtropical region of Jammu and Kashmir, India," Crop Protection, vol. 67, pp. 191199, 2015.

[33] M. J. Mohd Fuad, A. B. Junaidi, A. Habibah et al., "The impact of pesticides on paddy farmers and ecosystem," Advances in Natural and Applied Sciences, vol. 6, no. 1, pp. 65-70, 2012.

[34] R. Srinivasan, "Integrating biopesticides in pest management strategies for tropical vegetable production," Journal of Biopesticides, vol. 5, pp. 36-45, 2012.

[35] M. Bux, M. H. Khan, N. Ahmad, M. Tofique, and M. Ismail, "Field comparison of different rice (Oryza sativa $\mathrm{L}$ ) genotypes for their resistance against rice stem borers (Pyralidae: Lepidoptera)," Pakistan Journal of Agriculture Agricultural Engineering Veterinary Sciences, vol. 29, no. 2, pp. 137-145, 2013.

[36] D. Singh, A. K. Singh, and A. Kumar, "On-farm evaluation of integrated management of rice yellow stem borer (Scirpophaga incertulas Walk.) in Rice-Wheat Cropping System under Low Land Condition," Journal of AgriSearch, vol. 1, no. 1, pp. 40-44, 2014.

[37] C. O. Ehi-Eromosele, O. C. Nwinyi, and O. O. Ajani, "Integrated pest management," in Weed and Pest Control-Conventional and New Challenges, S. Soloneski and M. Larramendy, Eds., chapter 5, InTech, Rijeka, Croatia, 2013.

[38] S. Alam, "Checklist of rice insect pests of Bangladesh," in Literature Review of Insect Pests and Diseases of Rice in Bangladesh, pp. 79-90, Bangladesh Rice Research Institute (BRRI), Dhaka, Bangladesh, 1977.

[39] P. C. Jepson, M. Guzy, K. Blaustein et al., "Measuring pesticide ecological and health risks in West African agriculture to establish an enabling environment for sustainable intensification," Philosophical Transactions of the Royal Society of London Series B: Biological Sciences, vol. 369, no. 1639, Article ID 20130491, 2014.

[40] S. Parveen, "Rice farmers' knowledge about the effects of pesticides on environmental pollution in Bangladesh," Bangladesh Research Publications Journal, vol. 3, no. 4, pp. 1214-1227, 2010.

[41] S. B. Nerilo, F. A. Martins, L. B. Nerilo et al., "Pesticide use and cholinesterase inhibition in small-scale agricultural workers in southern Brazil," Brazilian Journal of Pharmaceutical Sciences, vol. 50, no. 4, pp. 783-791, 2014.

[42] World Health Organization (WHO), "Preventive disease through healthy environments," 2010, http://www.who.int/ipcs/ features/hazardous_pesticides.pdf.

[43] H. Berga and N. T. Tamb, "Use of pesticides and attitude to pest management strategies among rice and rice-fish farmers in the Mekong Delta, Vietnam," International Journal of Pest Management, vol. 58, no. 2, pp. 153-164, 2012.

[44] H. Andersson, D. Tago, and N. Treich, "Pesticides and health: a review of evidence on health effects, valuation of risks, and benefit-cost analysis," in Preference Measurement in Health, G. Blomquist and K. Bolin, Eds., Advances in Health Economics and Health Services Research, pp. 1-61, 2014, http://www2 .toulouse.inra.fr/lerna/travaux/cahiers2014/14.05.406.pdf.

[45] G. P. Fitt, "Critical issues in pest management for a future with sustainable biofuel cropping," Current Opinion in Environmental Sustainability, vol. 3, no. 1-2, pp. 71-74, 2011.

[46] J. N. Pretty, A. D. Noble, D. Bossio et al., "Resource-conserving agriculture increases yields in developing countries," Environmental Science \& Technology, vol. 40, no. 4, pp. 1114-1119, 2006.

[47] The CGIAR, "Integrated Pest Management and Crop Healthbringing together sustainable agroecosystems and people's health," White Paper, SP-IPM Secretariat, International Institute of Tropical Agriculture (IITA), Ibadan, Nigeria, 2010.

[48] J. J. Farrar, M. E. Baur, and S. Elliott, "Impacts of the regional integrated pest management competitive grants program in the Western United States," July 2015, http://westernipm.org/ index.cfm/about-the-center/publications/special-reports/western-ripm-retrospective-full-pdf/.

[49] International Institute of Tropical Agriculture (IITA), "Integrated Pest management," 2015, http://www.iita.org/c/document_library/get_file?uuid=60ala863-45a5-4bcd-bb57-ef30acea07ac\&groupId $=25357$.

[50] O. Ortiz, J. Kroschel, J. Alcázar, R. Orrego, and W. Pradel, "Evaluating dissemination and impact of IPM: lessons from case studies of potato and sweet potato IPM in Peru and other Latin American countries," in Integrated Pest Management: Dissemination and Impact, R. Peshin and A. K. Dhawan, Eds., pp. 419-434, Springer, Dordrecht, Netherlands, 2009. 
[51] F. X. Côte, C. Abadie, R. Achard et al., "Integrated pest management approaches developed in the french west indies to reduce pesticide use in banana production systems," Acta Horticulturae, vol. 828, pp. 375-382, 2009.

[52] C. Hall, B. Knight, S. Ringrose, and O. Knox, "What have been the farm-level economic impacts of the global cultivation of GM crops?" 2013, http://www.environmentalevidence.org/ wp-content/uploads/2014/07/CEE11-002.pdf.

[53] J. J. Rasmussen, P. Wiberg-Larsen, A. Baattrup-Pedersen, R. J. Monberg, and B. Kronvang, "Impacts of pesticides and natural stressors on leaf litter decomposition in agricultural streams," Science of the Total Environment, vol. 416, pp. 148-155, 2012.

[54] R. A. da Silva, E. D. Quintela, G. M. Mascarin, J. A. F. Barrigossi, and L. M. Lião, "Compatibility of conventional agrochemicals used in rice crops with the entomopathogenic fungus Metarhizium anisopliae," Scientia Agricola, vol. 70, no. 3, pp. 152-160, 2013.

[55] O. Mück, "Integrated Pest Management for Rice Production in Nigeria," 2015, http://cari-project.org/wp-content/uploads/ 2015/05/CARI-Rice-IPM-Nigeria-Draft-Study.pdf. 

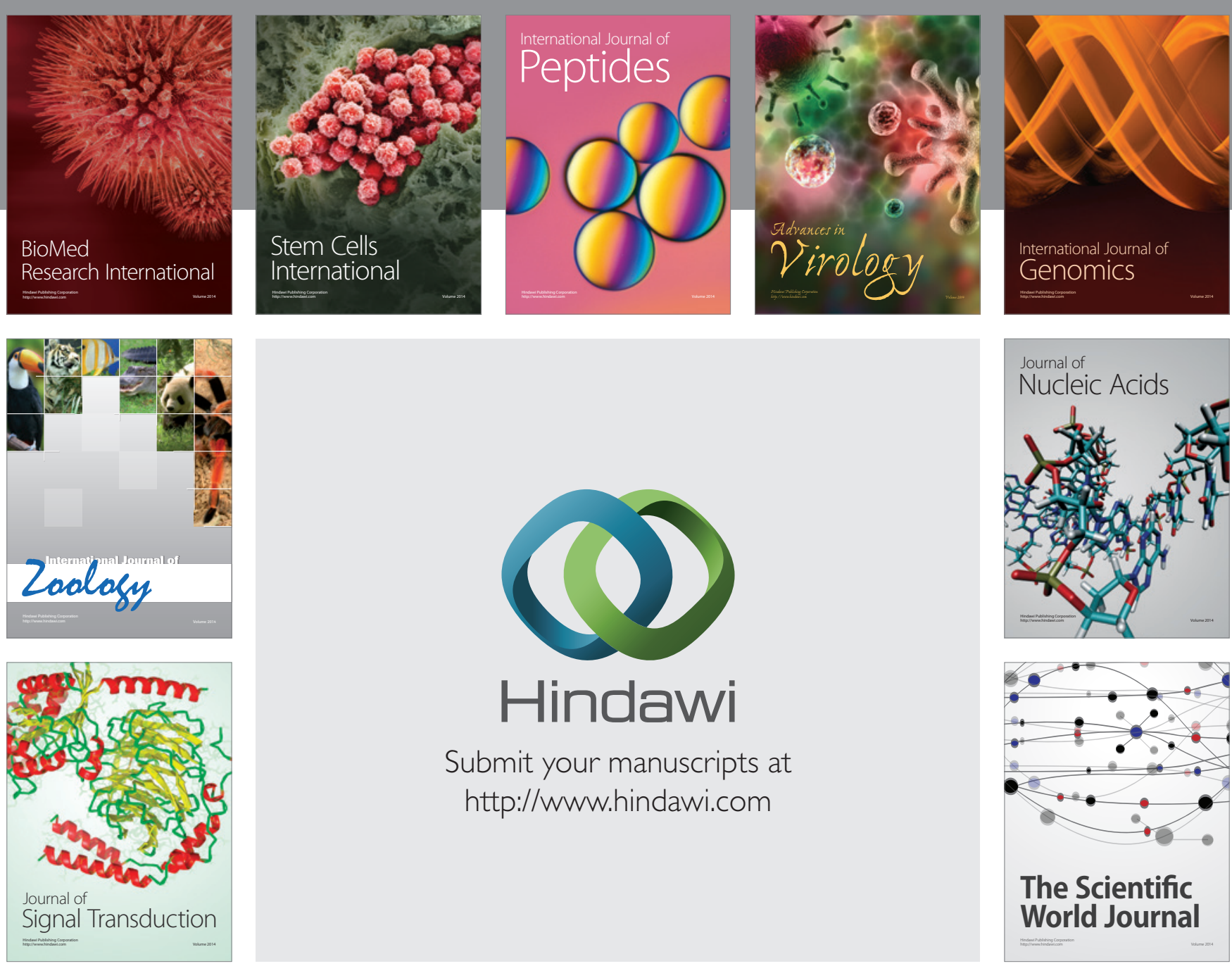

Submit your manuscripts at

http://www.hindawi.com
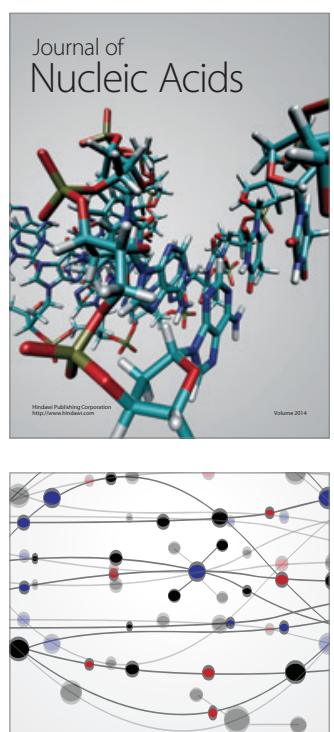

The Scientific World Journal
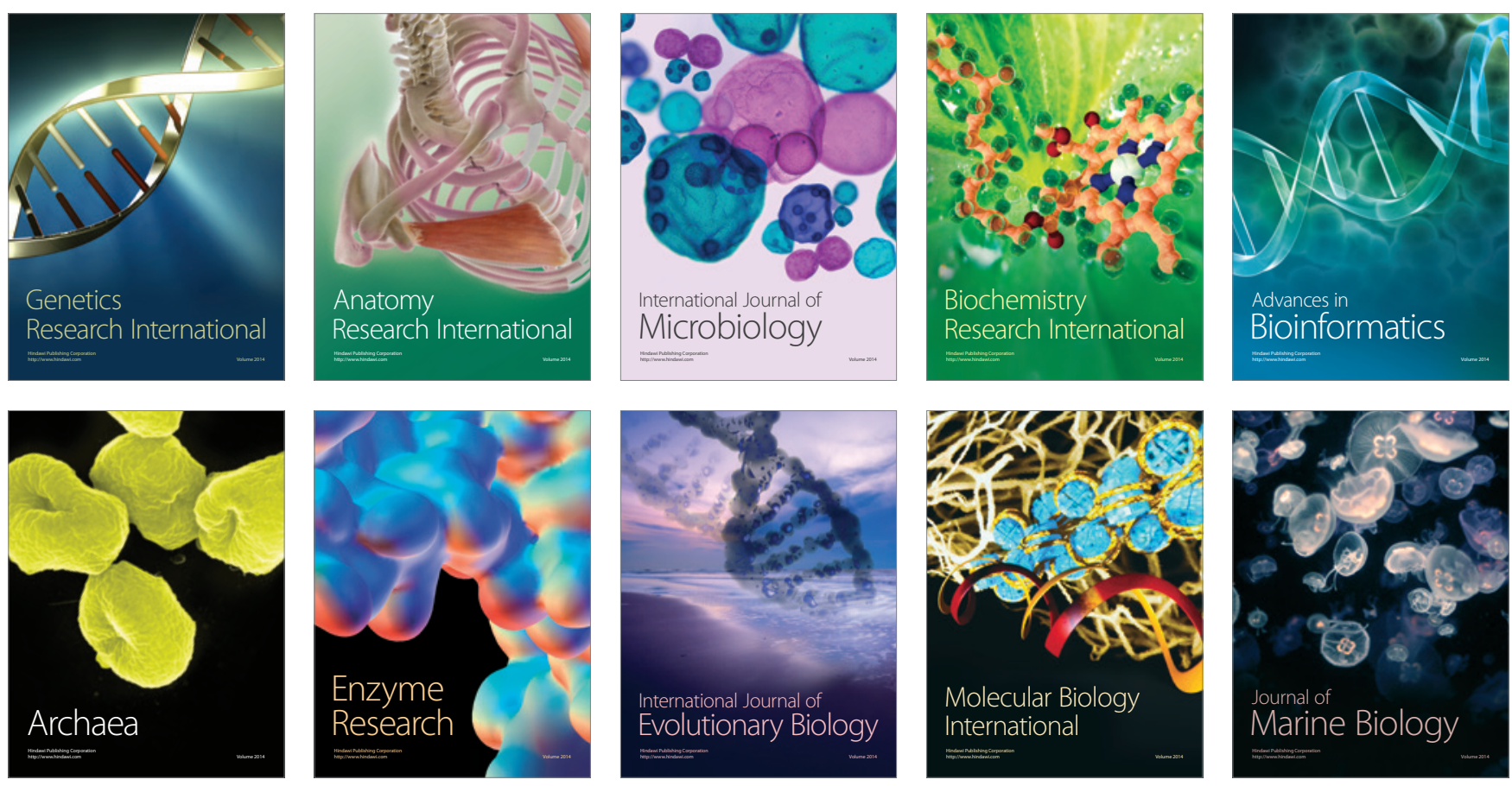